\title{
Analisa Desain Kemasan Stik Sukun (Artocarpus Altili) Menggunakan Metode Value Engineering
}

\author{
Anisha Dian Iswahyuni \\ Program Studi Teknik Industri, Fakultas Teknologi Industri, \\ Universitas Nahdlatul Ulama Al Ghazali Cilacap \\ e-mail: anisha.aza@gmail.com
}

\begin{abstract}
Abstrak
Desain kemasan sebuah produk menjadi daya tarik tersendiri bagi konsumen. Pemilihan desain yang tepat akan mampu meningkatakan penjualan sebuah produk. Tujuan penelitian ini adalah mendapatkan kemasan yang terbaik dengan merancang atau membuat konsep kemasan yang sesuai dengan kebutuhan dan keinginan konsumen berdasarkan analisa kemasan yang digunakan. Metode pengembangan kemasan yang dilakukan dengan pendekatan pengembangan produk dan value engineering dengan mengembangkan performansi berdasarkan keinginan konsumen dengan menggunakan metode FAST (Function Analysis System Technique). Hasil identifikasi kebutuhan konsumen, tahap pengujian dan pemilihan alternatif-alternatif konsep pengembangan kemasan terhadap analisa konsep maka akhir dari produk kemasan stik sukun terpilih adalah kemasan printing custom packaging berbahan dasar pouch padat alumuniumfoil custom ukuran $14 \times 23 \mathrm{~cm}$, stiker printing, memiliki desain full printing, ukuran netto 100-200gr, warna dasar kemasan gold/emas, varian rasa original, harga berkisar Rp.10.000,- sd Rp.20.000,-, menggunakan segel (sealer) dan memiliki legalitas PIRT dan Halal. Dengan kemasan hasil usulan diharapkan mampu meningkatkan pemasaran produk stik sukun.
\end{abstract}

Kata kunci: Value Engineering; FAST; Desain Kemasan

\begin{abstract}
The packaging design of a product is a special attraction for consumers. The right design would be able to increase sales of a product. The purpose of this research is to get the best packaging by designing or creating a packaging concept according to the needs and desires of consumers based on the packaging analysis used. The packaging development method is carried out with a product development approach and value engineering by improving performance based on consumer desires using the FAST method (Function Analysis System Technique). Based on the results of the identification of consumer needs, the testing phase, and the selection of alternative packaging development concepts to the concept analysis, the final product for the selected breadfruit stick packaging is a custom packaging printing made of solid aluminum foil pouch, with the custom size of $14 \times 23 \mathrm{~cm}$, printed sticker, full printed design, net size 100-200 grams, packaging basic color of gold, original flavor variant, the price ranges from Rp. 10,000 to Rp. 20,000, using a seal (sealer) and having PIRT and Halal certification. With the proposed packaging, it is hoped that the sales of breadfruit stick products would be increased.
\end{abstract}

Keywords: Value Engineering; FAST; Packaging Design

Diterima: 7 Oktober 2020

Disetujui: 28 Desember 2020

(C2020 Anisha Dian Iswahyuni

Dipublikasi: 30 Desember 2020

Under the license CC BY-SA 4.0

\section{Pendahuluan}

Kabupaten Cilacap merupakan kota pariwisata yang terletak di ujung selatan pulau Jawa, khususnya provinsi Jawa Tengah. Wilayahnya yang sangat luas menjadikan Kabupaten Cilacap kaya sumber daya alam. Salah satunya adalah tanaman buah sukun (Artocarpus Altili) yang tumbuh dibanyak pekarangan warga. Hal 
ini menjadikan buah sukun melimpah dan belum dimanfaatkan lebih maksimal dalam pengolahnnya.

Buah sukun yang melimpah merangsang banyak ide dari pelaku usaha untuk mengolahnya menjadi makanan yang memiliki nilai jual tinggi, seperti aneka sriping dan stik sukun yang dikombinasikan dengan varian rasa. Pengetahuan masyarakat pelaku usaha saat ini terbatas pada proses produksi saja, tanpa memikirkan inovasi produk dan kemasan yang menarik yang mampu meningkatkan pejualan. Keterbatasan bentuk kemasan yang masih sederhana hanya menggunakan plastik transparan dan label sederhana akan mempengaruhi daya beli konsumen, selain itu juga mempengaruhi kualitas dan ketahanan waktu simpan dari makanan yang menjadikan produk kurang memiliki daya tarik. Hasil panen buah sukun ketika musim panen tiba sangat melimpah sehingga dijadikan produk makanan khas Kabupaten Cilacap. Peneliti tertarik untuk menambah nilai jual dari olahan tersebut dengan memberikan usulan desain kemasan olahan sukun yang nantinya dapat menjadi daya tarik konsumen untuk membeli, untuk itu dibutuhkan desain kemasan yang menarik, informasi yang tepat mengenai nama, komposisi, produk,rasa yang terjaga jika dibawa bepergian dan sebagai buah tangan bagi para wisatawan, saudara dan sanak kerabat.

Inovasi membutuhkan 2 (dua) kondisi yang harus dipenuhi yaitu: novely (keterbaruan) dan utility (kegunaan). Secara umum, syarat keterbaruan diperoleh melalui invention (penemuan), scientiic discovery (temuan ilmiah), new production (produksi baru) atau management technique, guna menghasilkan fitur produk baru, yang dapat memenuhi kebutuhan konsumen. Inovasi produk tidak selamanya bergantung dari kemampuan untuk mengelola fungsi desain. Inovasi produk berbeda dengan inovasi proses, karena tidak memerlukan menggunakan metode dan peralatan serta menyediakan layanan pada konsumen (Lasalewo dkk, 2015). Pengukuran dengan pendekatan metode meta analisis menyimpulkan bahwa kegiatan inovasi secara umum dapat meningkatkan kinerja perusahaan, dan banyak ditemukan pada Industri Kecil dan Menengah/IKM. Pengenalan sebuah produk/jasa membutuhkan program perancangan desain identitas yang baik dan menerus, sehingga mampu unggul tidak hanya di media konvensioanal saja, namun merambah dunia maya melalui media sosial (Widyokusumo, 2014).

Daya tarik sebuah produk tentunya tidak terlepas dari desain kemasan sebuah produk. Desain dari sebuah kemasan merupakan identitas utama yang membedakan sebuah produk dengan produk sejenis lainnya dalam analisa kemasan minuman yang dilakukan oleh (Shierly \& Catherine, 2018). Kemasan juga harus memiliki fungsi 
strategis yang sifatnya mampu memberikan positioning baru dan leverage atau daya ungkit bagi sebuah produk diungkapkan (Julianti, 2014) dalam buku "The Art of Packaging". Pendekatan yang digunakan oleh (Klimchuk \& Krasovec, 2007) adalah pengembangan kemasan produk dengan metode value engineering (rekayasa nilai) karena dengan metode ini dapat diketahui spesifikasi kemasan yang diinginkan konsumen.

Metode yang dapat digunakan untuk membuat suatu inovasi produk kemasan adalah dengan value enggineering. Menurut Park (1999), value enggineering merupakan suatu sistem komplek yang dibuat untuk menentukan suatu tujuan dan mengembangkan beberapa alternatif sarana agar dapat mencapai tujuan yang telah dibuat sebelumnya. Menurut Hidayat (2012), value enggineering adalah suatu metode yang digunakan untuk memperoleh beberapa alternatif pilihan yang sangat efisien disertai pengeluaran biaya yang sekecil-kecilnya dan bertujuan untuk mendapatkan suatu performance tertentu. Menurut Satrio (2012), rekayasa nilai (value engineering) merupakan teknik pendekatan secara sistematis dari beberapa teknik, yang digunakan untuk mengidentifikasi dan menganalisa fungsi atau kegunaan dari suatu produk. Menurut Miles (1972), value engineering merupakan suatu teknik pendekatan spesifik yang tersusun secara kreatif terorganisir sehingga tidak perlu mengeluarkan biaya yang percuma.

Tujuan dari penelitian ini adalah 1) Mengidentifikasi kriteria pilihan konsumen yang didapat dari kuisioner dan wawancara agar digunakan sebagai penunjang untuk perancangan desain kemasan stik sukun; 2) Menganalisis alternatif pilihan menggunakan value engineering untuk mendapatkan performansi desain kemasan; dan 3) Produk usulan desain kemasan stik sukun.

\section{Metode}

Objek penelitian yang dijadikan bahan kajian adalah pengembangan desain kemasan stik sukun. Bahan baku yang digunakan dalam penelitian ini adalah kemasan stik sukun. Bahan kemasan yang digunakan adalah plastik standing pouch alumunium foil, stiker chrome, stiker printing, karton marga 310 gram dan plastik segel. Alat yang digunakan dalam penelitian ini adalah gunting, mistar, lem plastik, stapler, isolasi dan sealer.

Populasi dalam penelitian ini adalah jumlah penduduk dikota Cilacap yaitu $\pm 1,937,427$ jiwa (http://cilacapkab.bps.go.id/stastictable/2020/07/13/25). Sample adalah sebagian populasi yang diselidiki. Oleh karena itu harus dapat mewakili dan 
mencerminkan populasi yang ada. Ukuran sampel adalah banyaknya individu, subjek atau elemen dan dapat ditentukan dengan persamaan Slovin (Sugiyono, 2017) berikut:

$$
\mathrm{n}=\frac{\mathrm{N}}{1+\mathrm{Ne}^{2}}
$$

Keteragan:

$\mathrm{n}=$ ukuran sampel

$\mathrm{N}=$ ukuran populasi

$\mathrm{E}=$ persen kelonggaran ketidak telitian karena kesalahan pengambilan sampel yang masih ditolerir (error)

Dalam penelitian ini dipergunakan error 10\% dengan tingkat kepercayaan 95\% (tingkat signifikansi 5\%). Berdasarkan rumus Slovin tersebut, ukuran sampel yang harus diambil adalah:

$$
\mathrm{n}=\frac{1,937,427}{1+1,937,427(0,1)^{2}}=99,9948 \approx 100
$$

Jadi, jumlah sampel yang diambil untuk dijadikan sebagai responden adalah 100 responden.

Analisa pengembangan desain kemasan stik sukun dilakukan berdasarkan tahapan-tahapan dalam metode value engineering, yaitu tahap informasi, tahap kreatifitas, dan tahap analisa (Berawi, 2014; Carvel, 2007), seperti disajikan pada gambar 1.

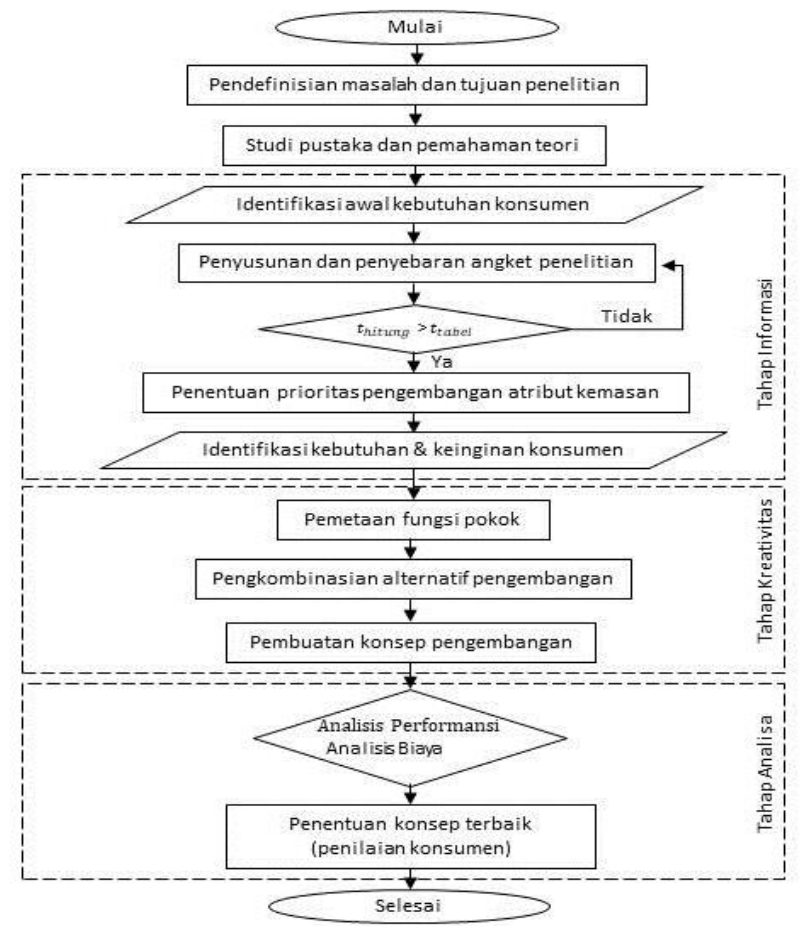

Gambar 1 Diagram Alir Penelitian 


\section{Tahap informasi}

Dalam tahapan ini dilakukan 5 langkah, yaitu:

1. Identifikasi atribut mutu kemasan. Identifikasi atribut kemasan dilakukan dengan wawancara terhadap beberapa konsumen dan produsen stik sukun.

2. Penyusunan dan Penyebaran Angket. Pengumpulan data yang berisi tentang informasi kebutuhan konsumen dilakukan untuk mengetahui tingkat kepentingan atribut kemasan yang telah diidentifikasi.

3. Pengujian validasi dan realibilitas. Hasil uji validitas menggunakan software SPSS 20.0 .

4. Penentuan tingkat kepentingan relative atribut kemasan. Penentuan tingkat kepentingan relative atribut kemasan bertujuan untuk menentukan priorotas pada pengembangan desain kemasan. Dengan adanya perangkingan prioritas dari atribut mutu desain kemasan, maka konsep perencanaan desain kemasan dapat kita rangking berdasarkan prioritas dari atribut tersebut. Identifikasi Kebutuhan dan keinginan konsumen.

Dari hasil angket penelitian tersebut maka kebutuhan dan keinginan konsumen akan pengembangan kemasan stik sukun dapat ditentukan berdasarkan persentase jawaban responden.

\section{Tahap Kreatifitas}

Bertujuan untuk mengembangkan sebanyak mungkin alternatif yang bisa dikembangkan untuk mengatasi permasalahan yang ada dan memenuhi kriteria yang dijelaskan pada tahap informasi (Julianti, 2014). Tahap kreatifitas terdiri dari 2 (dua) langkah, yaitu:

1) Pemetaan fungsi kemasan. Proses identifikasi dan pemetaan keterkaitan antara fungsi-fungsi dari kemasan dengan memanfaatkan diagram FAST (function analysis system technology), yang diitunjukkan pada gambar 2 . 


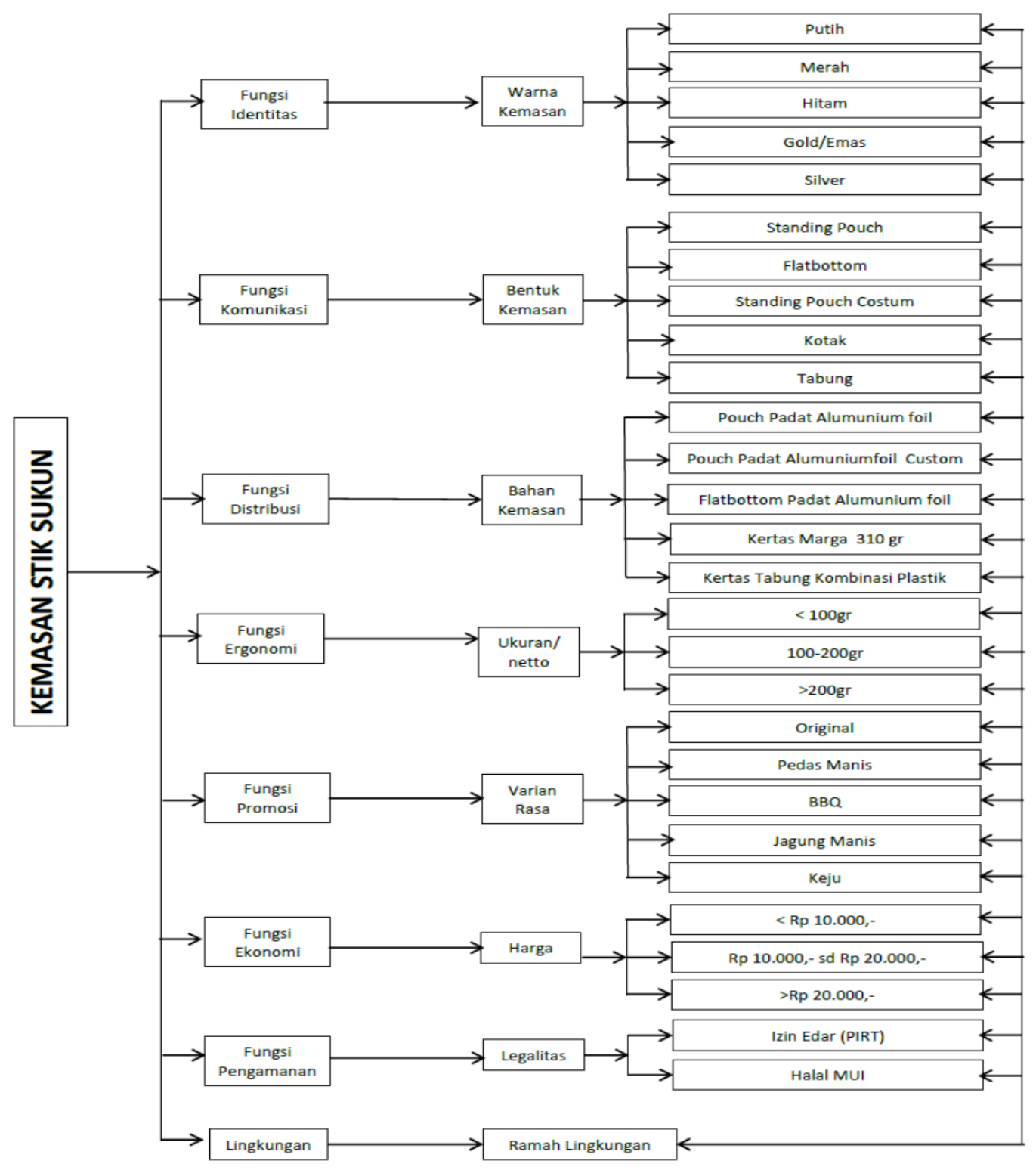

Gambar 2 Diagram FAST

2) Kombinasi alternatif konsep pengembangan kemasan

Alternatif yang muncul dalam pengembangan kemasan stik sukun menyangkut atribut desain kemasan dari responden dan produsen untuk mendapatkan desain kemasan stik sukun yang optimal sehingga mendapatkan nilai tambah dari produk.

\section{Tahap Analisa}

Tahap analisis bertujuan untuk menganalisa dan menyeleksi hasil pengujian yang telah dilakukan untuk menentukan konsep-konsep kemasan yang telah dirancang sehingga diperoleh rancangan konsep terbaik. Dasar penilaian konsep desain kemasan yang terbaik adalah konsep yang memiliki nilai (value) tertinggi. 


\section{Hasil dan Pembahasan}

Data lapangan yang telah ditemukan melalui pengamatan atau observasi, wawancara, kuesioner dan studi dokumentasi, kemudian dilakukan analisis deskriptif kemasan stik sukun, dengan inovasi kemasan menggunakan alumuniumfoil printing packaging. Objek dalam penelitian ini yaitu analisis dan konsep inovasi kemasan stik sukun. Objek Penelitian yaitu pada pelaku usaha stik sukun di Kecamatan Cilacap Tengah Kabupaten Cilacap.

Penulis melakukan dugaan sementara atau hipotesis untuk menentukan fokus atau garis besar penelitian. Namun, fokus penelitian tersebut hanya bersifat sementara yang harus diteliti kebenarannya melalui pengumpulan bukti atau data yang sebenarnya. Dugaan sementara atau hipotesis penelitian ini yaitu kemasan stik sukun merupakan kemasan sederhana dimana para pelaku usaha stik sukun kurang memiliki kemampuan dan dana untuk membuat kemasan stik sukun yang baik dan menarik.

\section{Hasil}

Tahap informasi

Dalam tahapan ini hasil yang diperoleh sebagai berikut:

1) Identifikasi atribut mutu kemasan. Hasil dari identifikasi atribut didapatkan 8 atribut kemasan stik sukun, yaitu bahan kemasan, desain kemasan, warna kemasan, ukuran kemasan, varian rasa, biaya produksi, kenyaman kemasan dan keramahan lingkungan

2) Penyusunan dan penyebaran angket penelitian. Penyebaran angket penelitian dan wawancara untuk mengetahui keakuratan atribut kemasan dilakukan kepada 100 responden.

3) Pengujian validasi dan realibilitas. Hasil uji validitas menggunakan software SPSS 20.0, semua atribut menunjukkan angka valid. Untuk angket penelitian bagian $B$ dengan atribut yang diajukan semua menunjukkan angka valid yaitu dengan $0.561,0.639,0.731,0.587,0.615,0.641,0.725$ dan 0.625 . Untuk angket penelitian bagian $\mathrm{C}$ semua atribut kemasan yang diajukan dari telah menunjukkan angka valid dan di atas angka $r$ table yaitu 0.195. Uji realibilitas menggunakan metode Cronbach's Alpha. Kuesioner dikatakan realibel apabila nilai koefisien Alpha lebih besar dari 0.6 (Hasil uji realibilitas terhadap angket penelitian bagian B telah menunjukkan angka reliable yaitu 0.791 .

4) Penentuan tingkat kepentingan relative atribut kemasan. Dengan adanya perangkingan prioritas dari atribut mutu desain kemasan, maka konsep 
perencanaan desain kemasan dapat kita rangking berdasarkan prioritas dari atribut tersebut.

Tingkat Kepentingan Relatif $=\frac{\text { rata-rata nilai atribut }}{\text { total rata-rata nilai semua atribut }} \times 100 \%$

5) Identifikasi Kebutuhan dan keinginan konsumen

Dari hasil angket penelitian tersebut maka kebutuhan dan keinginan konsumen akan pengembangan kemasan stik sukun dapat ditentukan berdasarkan persentase jawaban responden. Rumus sebagai berikut:

$$
=\frac{\text { jumlah responden yang memilih alternatif atribut }}{\text { jumlah responden keseluruhan }} \times 10 \%
$$

Pengembangan prioritas pada alternative pengembangan dengan persentase terbesar dan menghasilkan beberapa informasi sebagai berikut:

1) Kemasan $A$

Berbahan dasar pouch padat alumuniumfoil custom 14x23, bentuk kerucut, stiker crom, ukuran netto100-200gram, warna gold/emas, menggunakan segel (sealer), harga Rp.10.000,- s/d Rp. 20.000,-.

2) Kemasan $B$

Berbahan dasar bottomflat padat alumuniumfoil 11,5×18, bentuk kotak, stiker chrom, ukuran netto 100-200gr, warna gold/emas, menggunakan segel (sealer), harga Rp.10.000,- s/d Rp. 20.000,--

3) Kemasan $\mathrm{C}$

Berbahan dasar pouch padat alumuniumfoil $14 \times 23$, stiker printing, ukuran netto100-200gr, warna gold/emas, menggunakan segel (sealer), harga Rp.10.000,- s/d Rp. 20.000,--

4) Kemasan $D$

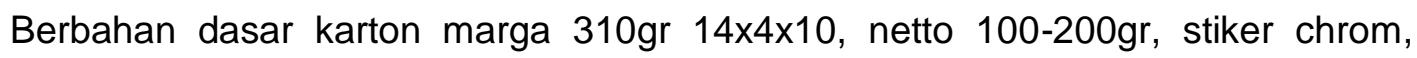
warna gold/emas, menggunakan segel (sealer), harga Rp.10.000,- s/d Rp. $20.000,-$.

5) Kemasan $\mathrm{E}$

Berbahan dasar kertas $17 \times 7.5 \mathrm{~cm}$, stiker chrome, netto 100-200gr, warna gold/emas, menggunakan segel, harga Rp.10.000,- s/d Rp. 20.000,-.

Dari hasil perhitungan biaya bahan baku akan didapatkan biaya perkemasan untuk setiap konsep. Dan kemudian dari hasil perhitungan biaya tersebut kemudian dihitungkan value untuk setiap alternatif konsep dan kemudian dilakukan 
perangkingan. Sehingga diperoleh nilai sebagaimana disajikan pada tabel 1 dan gambar 3.

Tabel 1 Perangkingan Alternati Konsep

\begin{tabular}{|c|c|c|c|c|c|c|c|}
\hline No & Alternatif & Performance & Cost & & $\begin{array}{l}\text { i nilai } \\
\text { ance } \\
\text { atuan } \\
\text { g }\end{array}$ & Value & Rangking \\
\hline 1 & A & 18 & 2010 & $\mathrm{Rp}$ & 2,010 & 0.896 & 2 \\
\hline 2 & B & 14 & 2620 & $\mathrm{Rp}$ & 2,620 & 0.534 & 3 \\
\hline 3 & C & 56 & 2500 & $\mathrm{Rp}$ & 2,500 & 2.240 & 1 \\
\hline 4 & D & 5 & 1750 & $\mathrm{Rp}$ & 1,750 & 0.286 & 4 \\
\hline 5 & $E$ & 7 & 4750 & $\mathrm{Rp}$ & 4,750 & 0.147 & 5 \\
\hline
\end{tabular}

\begin{tabular}{|c|c|c|}
\hline Rank & Desain Terpilih & Spesifikasi \\
\hline 1 & Alternatif $\mathrm{C}$ & $\begin{array}{l}\text { - Berbahan dasar pouch padat alumuniumfoil custom } \\
14 \times 23 \\
\text { - stiker printing, } \\
\text { - ukuran netto100-200gr, } \\
\text { - warna gold/emas, } \\
\text { - varian rasa original } \\
\text { - menggunakan segel (sealer), } \\
\text { - harga Rp.10.000,- sd Rp.20.000,- } \\
\text { - Legalitas PIRT dan Halal }\end{array}$ \\
\hline 2 & Altern & $\begin{array}{l}\text { - Berbahan dasar pouch padat alumuniumfoil } 14 \times 23 \\
\text { - stiker chrome, } \\
\text { - ukuran netto100-200gr, } \\
\text { - warna gold/emas, } \\
\text { - varian rasa original } \\
\text { - menggunakan segel (sealer), } \\
\text { - harga Rp. } 10.000,- \text { sd Rp. } 20.000,-\end{array}$ \\
\hline 3 & Alternatif B & $\begin{array}{l}\text { - } \text { Berbahan dasar flatbottom padat alumuniumfoil } \\
11,5 \times 18 \\
\text { - stiker chrome } \\
\text { - ukuran netto100-200gr, } \\
\text { - warna gold/emas, } \\
\text { - varian rasa original } \\
\text { - menggunakan segel (sealer), } \\
\text { - harga Rp.10.000,- sd Rp.20.000,- }\end{array}$ \\
\hline 4 & Alternatif $D$ & $\begin{array}{l}\text { - Berbahan dasar karton marga } 310 \text { gr } 14 \times 4 \times 10 \\
\text { - Laminasi Luar } \\
\text { - Ukuran netto100-200gr, } \\
\text { - warna gold/emas, } \\
\text { - varian rasa original } \\
\text { - menggunakan segel (sealer), } \\
\text { - harga Rp.10.000,-- sd Rp.20.000,- }\end{array}$ \\
\hline
\end{tabular}




\begin{tabular}{|l|c|l|}
\hline 5 & Alternatif C & $\begin{array}{l}\text { - Berbahan kertas } 17 \times 7,5 \mathrm{~cm} \\
\text { - stiker chrome, } \\
\text { - ukuran netto100-200gr, } \\
\text { - warna gold/emas, }\end{array}$ \\
& $\begin{array}{l}\text { - menggunakan segel (sealer), } \\
\text { - varian rasa original } \\
\text { - harga Rp.10.000,- sd Rp.20.000,- }\end{array}$ \\
\end{tabular}

Gambar 3 Desain Alternatif

\section{Pembahasan}

Mengacu pada metode penelitian yang digunakan maka diperoleh 8 atribut kemasan stik sukun yaitu bahan kemasan, desain kemasan, warna kemasan, ukuran kemasan, varian rasa, biaya produksi, kenyaman kemasan dan keramahan lingkungan. Atribut tersebut sejalan dengan penelitian yang dilakukan pada desain kemasan Yogurt Drink 'CIMORY' oleh (Everline \& Yosephine, 2018). Atribut kemasan stik sukun tersebut menjadi dasar pengembangan inovasi kemasan yang dikombinasikan dengan metode value engineering sebagai desain alternatif terpilih adalah kemasan printing custom packaging berbahan dasar pouch padat alumuniumfoil yang diharapkan mampu meningkatkan penjualan pemasaran produk stik sukun.

Penelitian sebelumnya juga dilakukan (Lailiyah et al., 2019) pada produk terasi bonang dengan inovasi iconing printing packaging sebagai solusi menghadapi industri 4.0. Pada penelitian lain, Mardiana (2017) mengusulkan desain kemasan ikan asin lome menggunakan metode value engineering sebagai solusi pemasaran produk di era digital. Faktor psikologis dalam pemilihan kemasan juga menjadi perhatian yang cukup menarik sehingga pengembangan desain kemasan yang sesuai dengan keinginan konsumen untuk meningkatkan angka penjualan menjadi fokus penelitian oleh (Titaley et al., 2018).

Value Engineering sebagai teknik aplikasi pendekatan untuk mengidentifikasi fungsi suatu produk atau jasa dan untuk mengembangkan fungsi tersebut pada biaya rendah. Value Engineering sebagai metode untuk meningkatkan nilai produk dengan meningkatkan hubungan antara fungsi produk dan biayanya menurut (Berawi, 2012). Value Engineering diimplementasikan melalui proses rasional yang sistematis yang meliputi fungsi analisis untuk mendefinisikan keberadaan barang/komponen stik sukun, teknik kreatif dan spekulatif untuk membuat alternatif baru desain kemasan inovasi. Teknik pengukuran untuk evaluasi nilai sekarang dan konsep desain inovasi yang akan diusulkan berupa desain kemasan printing custom packaging berbahan dasar pouch 
padat alumuniumfoil, dengan ukuran $14 \times 23 \mathrm{~cm}$, berwarna gold/emas, netto produk 100-200 gram, varian rasa original, rentang harga jual yang diinginkan konsumen $\mathrm{Rp}$ 10.000-Rp 20.000, memiliki perizinan PIRT dan Halal, serta mengunakan segel (sealer) menjadi nilai tambah tertinggi pada penentuan rangking identifikasi kebutuhan konsumen.

\section{Kesimpulan}

Berdasarkan pembahasan tersebut dapat disimpulkan bahwa kemasan stik sukun yang sudah ada menggunakan plastik ukuran $10 \mathrm{oz}$ dengan kemasan sablon di Kabupaten Cilacap masih sederhana. Sehingga belum bisa bersaing lebih luas dipasar modern. Kualitas makanan menggunakan plastik yang ada saat ini memiliki umur simpan yang relatif pendek karena jenis bahan kemasan yang digunakan. Melihat kondisi tersebut mendorong penulis untuk menawarkan desain kemasan stik sukun yang sudah dilakukan riset dari konsumen. Kemasan terpilih pada kemasan printing custom packaging berbahan dasar pouch padat alumuniumfoil, dengan spesifikasi warna gold/emas, netto 100-200gr, varian rasa original, rentang harga jual yang diinginkan konsumen $\mathrm{Rp}$ 10.000-Rp 20.000, memiliki perizinan PIRT dan Halal, serta mengunakan segel (sealer). Kemasan alumuniumfoil diharapkan mampu memiliki umur simpan yang lebih lama dibanding plasik sebelumnya. Dengan adanya penelitian ini diharapkan mampu memberikan kontribusi pagi palaku usaha stik sukun untuk memberikan konsep desain yang diminati konsumen sehingga produk stik sukun dapat bertahan dan bersaing di era industri 4.0.

\section{Daftar Pustaka}

Berawi, M.A. (2014). Aplikasi value engineering pada industri konstruksi bangunan gedung. Jakarta: UI Press.

Calver, Giles. (2007). What is packaging design? Singapore: Page One Publishing Private Limited.

Everlin, S., \& Yosephine, C. (2018). Analisis desain kemasan Yogurt Drink 'CIMORY' analysis of 'Cimory' Yogurt Drink Packaging. Jurnal Titik Imaji, 1(2), 109-121.

Hidayat, R., \& Arenda, A. (2012). Re-design mesin fermentasi roti menggunakan Pendekatan Value Engineering (VE). Industrial and Systems Engineering Assessment Journal (INASEA), 13(2).

Julianti, S. (2014). The art of packaging. Jakarta: PT Gramedia Pustaka Utama.

Klimchuk, M.R. dan Krasovec, S.A. (2007). Desain kemasan. Jakarta: Erlangga 
Lailiiyah, N., Muatsiroh, F., \& Wirawan, M.L. (2019). Analisis kemasan terasi bonang Kabupaten Rembang serta inovasinya (iconing printing packaging) untuk menghadapi Industri 4.0. Seminar dan Konferensi Nasional IDEC, ISSN: 2579-6429.

Lasalewo, T., Subagyo, Hartono, B., \& Yuniarto, H.A. (2015). Perspektif pengembangan produk berdasarkan kajian literatur. Free Trade Engineers: Opportunity or Threat? The 5th Annual Engineering Seminar, 113-120.

Mardiana. (2017). Usulan desain kemasan ikan asin Lome menggunakan metode Value Engineering. Jurnal Tenik Industri UNISI, 1(1), 11-19.

Miles, L., (1972). Tecniques of value analysis and engineering. New York: Mc. GrawHill.

Park, J.R. (2000). Value engineering a plant for invention. New York: St. Lucie Press

Satrio, W.A. (2012). Alat tambal ban elektrik dengan Pendekatan Value Engineering. Tugas Akhir. Universitas Wijaya Putera.

Sugiyono. (2017). Metode penelitian kuantiitatif, kualitatif, dan $R \& D$. Bandung: Alfabeta, CV.

Titaley, S., Kakerissa, A.L., \& Tukoboya, A.R. (2018). Desain kemasan minuman bubuk sari pala menggunakan metode engineering. Seminar Nasional "Archipelago Engineering" (ALE), ISSN: 2620-3995.

Widyokusumo, L. (2014). Meningkatkan citra UKM melalui perancangan ulang identitas visual. HUMANIORA, 5(1), 163-171. 